\title{
Isolated salpingeal torsion in children: a case series and review of the literature
}

\author{
Volkan Sarper Erikci, M.D., Münevver Hoşgör, M.D. \\ Department of Pediatric Surgery, Dr Behçet Uz Children Hospital, İzmir
}

\begin{abstract}
This study was carried out to evaluate and determine the history, clinical presentation, and physical examination and laboratory findings in a pediatric $(n=I)$ and adolescent $(n=2)$ population with isolated tubal torsion (ITT) and to examine its surgical management. A retrospective review of all the cases of ITT treated in our hospital between January 2000 and December 2012 was performed. The diagnosis of ITT was performed by physical examination and radiological studies including ultrasonography (US), color Doppler US, and computed tomography (CT) and confirmed by surgical intervention. There were 3 children with ITT in the study period. Two of the patients were adolescents and one was diagnosed in the neonatal period. Two patients had left-sided ITT. The neonatal patient was diagnosed with abdominopelvic mass antenatally. ITT in the other two children occurred three days after the onset of symptoms. All the patients in this study were treated with salpingectomy. ITT is rarely diagnosed preoperatively, and is treated mostly by salpingectomy. A better recognition of this entity may help to improve the treatment of this rare condition. As advocated for ovarian salvage in adnexal torsions, earlier diagnosis and preservation of the tube, if possible, with prompt surgical intervention may increase the future reproductive potential of these patients.
\end{abstract}

Key words: Children; isolated tubal torsion; salpingectomy.

\section{INTRODUCTION}

Torsion of the fallopian tube is an uncommon cause of abdominal pain in girls. When it is not associated with torsion of the ovary, the term isolated tubal torsion (ITT) is used. It is defined as the twisting by at least one complete turn of the fallopian tube around a center-line consisting of the infundibulopelvic ligament and tubo-ovarian ligament. ${ }^{[1]}$ ITT is observed in women of reproductive age, with an annual prevalence of I in I.5 million. ${ }^{[2]}$

Ischemia is the direct consequence of a twist in the fallopian tube. The interruption in the arterial blood supply may be the initial consequence of the TT, or develop secondarily to a pause in the venous flow due to the presence of edema. In the absence of treatment, it results in necrosis of the fallopian

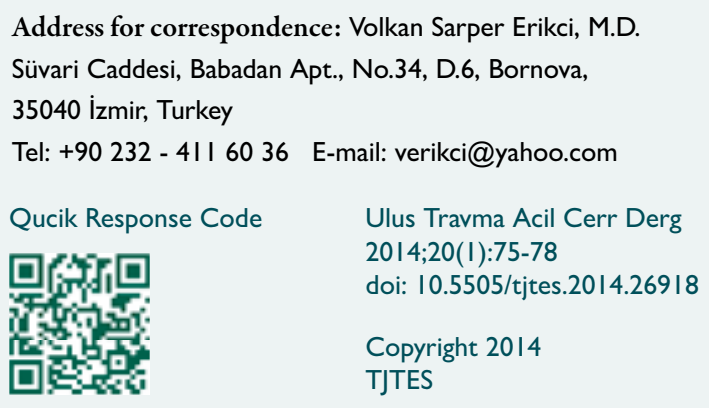

tube, which will be followed by loss of the organ and may adversely affect future fertility. ${ }^{[3-6]}$ More rarely, due to the release of cytokines, it may be the origin of potential fatal complications such as pelvic thrombophlebitis or peritonitis. ${ }^{[7]}$

In this article, we present three cases of ITT in order to determine the history, clinical presentation, and physical examination and laboratory findings in a pediatric $(n=l)$ and adolescent $(n=2)$ population and to examine its surgical management.

\section{CASE REPORT}

A retrospective review of all cases of ITT treated in the Department of Pediatric Surgery, Dr. Behçet Uz Children's Hospital, between January 2000 and December 2012 was performed. All cases of ITT sparing the ipsilateral ovary were included in this study. Exclusion criteria were fallopian tube torsion combined with ipsilateral ovarian torsion, medical history of pelvic surgery, pelvic inflammatory disease (PID), and tubal/ovarian malignancies, or pregnancy. Our case series consisted of three patients treated in our clinic.

Case I- A 14-year-old girl was admitted to the emergency room with pain in her lower right quadrant of three-days' duration and bilious vomiting for one day. She had her first menstrual period with the onset of the pain. Her physical examination revealed tenderness in the right lower quadrant 

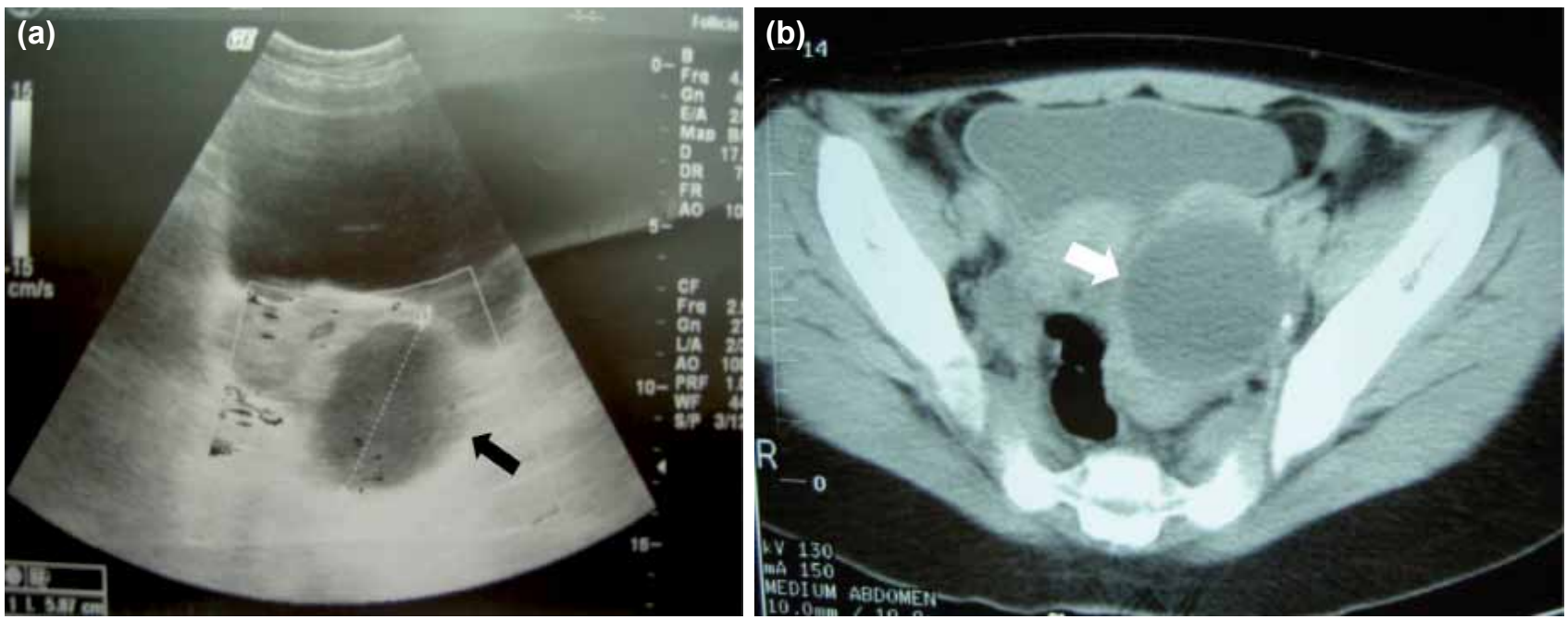

Figure 1. (a) Pelvic color Doppler US showing bilateral normal perfused ovaries with a cystic mass (Arrow: cystic mass). (b) Computed tomography showing the cystic mass (Arrow: cystic mass).

with mild guarding; the laboratory tests were unremarkable. Radiological evaluation with ultrasonography (US) and a color Doppler showed bilateral normal perfused ovaries with a cystic mass of $6 \mathrm{~cm}$ (Figure la). Computed tomography (CT) confirmed that the mass was cystic, with a dimension of $5 \times 6$ $\mathrm{cm}$ (Figure Ib). As TT with hydrosalpinx was diagnosed, the patient underwent an emergent exploration. The left ovary and fallopian tube were normal. The right ovary appeared increased in size, to double that of the left ovary, with multiple follicular cysts inside. The right fallopian tube with hydrosalpinx and a closed tip of the ampulla was found to be torsed $360^{\circ}$ clockwise, and it was untwisted to its neutral position (Figure 2a). As no change in color was observed in time, salpingectomy was performed. Histopathological evaluation of the specimen revealed hematosalpinx with hemorrhagic necrosis in all sections. She was discharged three days after the surgical intervention. Serial US assessments showed no signs of tubal or ovarian pathologies with both ovaries of equal dimensions during the follow-up of five years.
Case 2- A five-day-old female baby with an antenatal diagnosis of abdominal mass was admitted to our clinic. Her physical examination was unremarkable except for a mobile mass in the lower abdominal region. The laboratory tests were normal except for an increase in the ferritin levels $(376 \mathrm{ng} / \mathrm{ml}, \mathrm{N}: 25-$ $200 \mathrm{ng} / \mathrm{ml})$, lactate dehydrogenase (LDH) (900 u/L, N: 220-480 $\mathrm{u} / \mathrm{L})$ and alpha-fetoprotein $(36506 \mathrm{IU} / \mathrm{ml}, \mathrm{N}: 0-1400 \mathrm{IU} / \mathrm{ml})$. US revealed a $4 \times 5 \mathrm{~cm}$ mobile cystic mass with air-fluid level. CT confirmed the septated mass to be located under the liver with the majority of the mass being cystic in nature (Figure $2 b)$. At laparotomy, the left fallopian tube and ovary were normal. There was no right ovary, and the right tube was $0.5 \mathrm{~cm}$ in length with obliterated tip. A mass of $6 \times 5 \mathrm{~cm}$ in diameter connected to the tip of the appendix was found in the pelvis and resected with the appendix. Histopathological examination revealed a cystic mass with hemorrhagic infarction and dystrophic calcification in its wall and an inflamed appendix. It was considered as an in-utero TT with autoamputation. The postoperative course was uneventful, and she was discharged
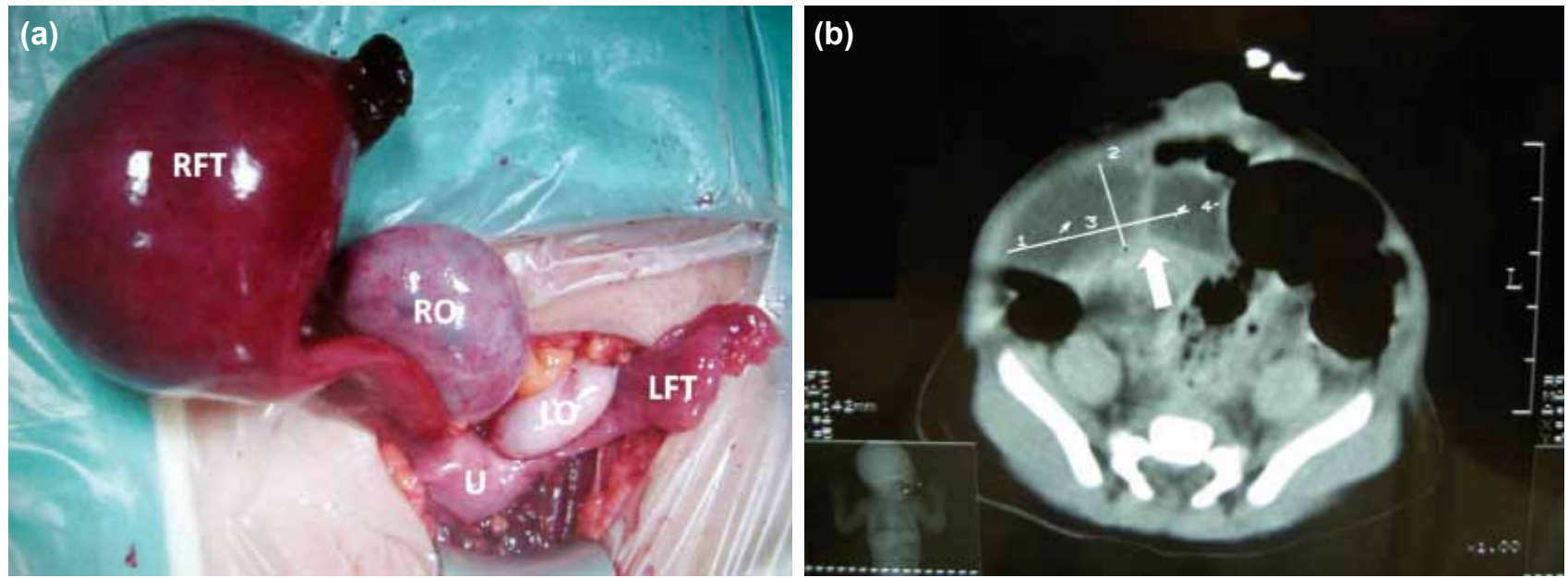

Figure 2. (a) Intraoperative image showing the detorsed right fallopian tube with hydrosalpinx (RFT: Right fallopian tube; RO: Right ovary; U: Uterus; LO: Left ovary; LFT: Left fallopian tube). (b) Computed tomography showing the septated cystic mass under the liver. 
from the hospital on the 4th postoperative day. One month after the surgical intervention, she was internalized with the diagnosis of brid ileus and treated conservatively. There has been no recurrence to date after a 12-year follow-up.

Case 3- A 13-year-old girl was admitted to our clinic with pain in her lower left quadrant of three-days' duration. Her menstruation had begun one year before, with regular cycles of 28-32 days. Her laboratory tests were unremarkable. On the physical examination, she had moderate tenderness on deep palpation of her left lower quadrant. A vaginal examination was not performed, and a digital rectal examination revealed a mass in the anterior region of the rectum. Apart from normal-appearing ovaries, US confirmed the presence of a mass containing no vascular flow on color Doppler. CT revealed a $9 \mathrm{~cm}$ septated mass separate from the uterus. Diagnostic laparoscopy revealed a $10 \mathrm{~cm}$ necrotic blue mass in the left pelvis. For a better exposure and easier removal of necrotic tissue, a laparotomy was performed, and a totally necrotic torsed left fallopian tube was resected with incidental appendectomy. The pathology report revealed extensive hemorrhagic infarction in the left fallopian tube. The postoperative course was uneventful, and she was discharged from the hospital on the 3rd postoperative day with no recurrence to date after a 12-year follow-up.

\section{DISCUSSION}

Since the initial description of pediatric adnexal torsion by Sutton, ${ }^{[8]}$ a number of adnexal torsion cases in childhood have been reported. ${ }^{[9]}$ ITT in childhood has been a rarely encountered pathology. There are several predisposing factors in this clinical entity, including abnormal tubal peristalsis, hydrosalpinx, tubal ligation or neoplasms, paraovarian/paratubal masses, uterine enlargement, adhesions following surgical interventions, or infections. ${ }^{[10]}$ In the pediatric age group, the possible factors are preexisting congenital malformations such as excessive tortuosity and elongation of the tube. ${ }^{[1,12]}$ In the absence of predisposing tubal pathologies, torsion of the fallopian tube is generally due to abnormal motility observed during early puberty due to the elevated follicle-stimulating hormone (FSH) level that triggers the tubal motility. $[12,13]$ Two of three patients in this study were adolescents, with similar ratios according to those reported.

The right side is most frequently affected in cases of adnexal torsion for two reasons. ${ }^{[14,15]}$ Due to the cushioning effect of the sigmoid colon, there is a preventive effect of anatomic positioning on the left side. The second reason is that rightsided pathology is evaluated more often in the context of the differential diagnosis of acute appendicitis. Despite these observations and the fact that the right utero-ovarian ligament is physiologically longer than the left, left-sided TTs reported in the literature outnumber those on the right. ${ }^{[2]}$ Two of three patients in our study had left-sided ITT, and this finding shows a similarity with those reported previously. As a result, further researches with larger series of patients are needed to shed a new light on the issue of dominant side in ITT.

Patients with ITT usually experience the sudden onset of intense pain. ${ }^{[7,16]}$ Pain lasting more than 10 hours before surgery is associated with an increased rate of tubal necrosis. ${ }^{[17]} \mathrm{Har}-$ mon et al. ${ }^{\left[{ }^{10]}\right.}$ presented a mean of 1.67 days (range, $0-5$ days) from initial imaging (not onset of pain) till surgery in patients with ITT, and all the cases required salpingectomy. With the exception of the neonatal case with an antenatal diagnosis of abdominal mass, late admissions were relevant in our study, as two of our patients presented intense abdominal pain of three-days' duration, and this clinical scenario resulted in tissue necrosis confirmed by the pathological examination.

Clinical examination may reveal latero-uterine mass in $4 \mathrm{I}$ $70 \%$ of cases..$^{[3,18]}$ However, in this study, only the neonatal case with intrauterine TT presented with a palpable mobile mass in the lower abdominal region. There is no additional biological investigation specific to adnexal torsion. US examination may reveal a pathological adnexal image in most cases, ${ }^{[15,19-21]}$ but these are not pathognomonic for ITT. Due to the dual vascular supply of the tubes, a normal Doppler cannot exclude the diagnosis of TT. ${ }^{[1]}$ CT or magnetic resonance imaging (MRI) can reveal the tubal mass but not signs of ischemia, unlike Doppler US. In one study, US, CT and MRI showed a sensitivity of $22 \%, 14 \%$ and $40 \%$ in diagnosing ITT, respectively. ${ }^{[22]}$ As a diagnostic tool, US was the first imaging modality in this study, but revealed nonspecific findings. A color Doppler US combined with pelvic CT was also used in the diagnostic work-up of these patients. However, the definitive diagnosis of TT with hydrosalpinx was possible in only one patient (Case 3) preoperatively. The only certain way to diagnose ITT is surgery, by laparoscopy or laparotomy.

There are 45 cases of ITT in the pediatric literature review, with a mean age of 13.2 years at presentation. ${ }^{[22]}$ Although similar to the literature with regard to the ages in this study (Case I: I 3 years; Case 3: I 4 years), this study is unique for its presentation of a neonatal baby with ITT. Because no normallooking right tube was observed during laparotomy, it was speculated that it presumably had torsed in utero, resulting in autoamputation. To our knowledge, there is no pediatric case of neonatal age with ITT in the English-language literature.

All the patients in this study were treated with salpingectomy. A literature review revealed that of the children with ITT, $88 \%$ were treated by salpingectomy, while $12 \%$ were treated by tubal detorsion; the long-term outcomes of detorsion were not reported. ${ }^{[22]}$ Salpingoneostomy was also reported as a therapeutic approach, and one case was treated with this modality with an uneventful follow-up of 26 months. ${ }^{[12]}$ ITT in children is still frequently misdiagnosed and is too often managed in a nonconservative manner, which compromises the fertility potential of pediatric patients before the beginning of their reproductive life. As detorsion and ovarian salvage is 
a safe choice no matter how necrotic the ovary appears, the same philosophical system may be applied to tubal salvage. ${ }^{[23,24]}$ After detorsion, a second-look surgical intervention may preserve potentially functional tubes.

Isolate tubal torsion in girls is rarely diagnosed preoperatively, and is treated mostly by salpingectomy. A better recognition of this entity with an interdisciplinary approach including pediatric surgeons and gynecologists may help to improve the treatment of this rare condition and open a new era in its management. As is commonly advocated for ovarian salvage in adnexal torsions, earlier diagnosis and preservation of the tube, if possible, with prompt surgical intervention may increase the future reproductive potential of these patients in general.

\section{Conflict of interest: None declared.}

\section{REFERENCES}

1. Huchon C, Fauconnier A. Adnexal torsion: a literature review. Eur J Obstet Gynecol Reprod Biol 2010;150:8-12. CrossRef

2. Lima M, Libri M, Aquino A, Gobbi D. Bilateral hydrosalpinx with asynchronous tubal torsion: an exceptional finding in a premenarcheal girl. J Pediatr Surg 2011;46:27-9. CrossRef

3. Bayer AI, Wiskind AK. Adnexal torsion: can the adnexa be saved? Am J Obstet Gynecol 1994;171:1506-11. CrossRef

4. Haskins T, Shull BL. Adnexal torsion: a mind-twisting diagnosis. South Med J 1986;79:576-7. CrossRef

5. Hibbard LT. Adnexal torsion. Am J Obstet Gynecol 1985;152:456-61.

6. Ozcan C, Celik A, Ozok G, Erdener A, Balik E. Adnexal torsion in children may have a catastrophic sequel: asynchronous bilateral torsion. J Pediatr Surg 2002;37:1617-20. CrossRef

7. Nichols DH, Julian PJ. Torsion of the adnexa. Clin Obstet Gynecol 1985;28:375-80. CrossRef

8. Sutton JB. Salpingitis and some of its effects. Lancet 1890;2:1146-8.

9. Sozen I, Nobel PA, Nobel J. Partial tubal salvage through neosalpingostomy in a 12-year-old girl with combined ovarian and fallopian tube torsion. J Pediatr Surg 2006;41:17-9. CrossRef
10. Harmon JC, Binkovitz LA, Binkovitz LE. Isolated fallopian tube torsion: sonographic and CT features. Pediatr Radiol 2008;38:175-9. CrossRef

11. James DF, Barber HR, Graber EA. Torsion of normal uterine adnexa in children. Report of three cases. Obstet Gynecol 1970;35:226-30.

12. Boukaidi SA, Delotte J, Steyaert H, Valla JS, Sattonet C, Bouaziz J, et al. Thirteen cases of isolated tubal torsions associated with hydrosalpinx in children and adolescents, proposal for conservative management: retrospective review and literature survey. J Pediatr Surg 2011;46:1425-31.

13. Merlini L, Anooshiravani M, Vunda A, Borzani I, Napolitano M, Hanquinet S. Noninflammatory fallopian tube pathology in children. Pediatr Radiol 2008;38:1330-7. CrossRef

14. Peña JE, Ufberg D, Cooney N, Denis AL. Usefulness of Doppler sonography in the diagnosis of ovarian torsion. Fertil Steril 2000;73:1047-50.

15. Warner MA, Fleischer AC, Edell SL, Thieme GA, Bundy AL, Kurtz $\mathrm{AB}$, et al. Uterine adnexal torsion: sonographic findings. Radiology 1985;154:773-5.

16. Goldstein DP. Acute and chronic pelvic pain. Pediatr Clin North Am 1989;36:573-80.

17. Mazouni C, Bretelle F, Ménard JP, Blanc B, Gamerre M. Diagnosis of adnexal torsion and predictive factors of adnexal necrosis. [Article in French] Gynecol Obstet Fertil 2005;33:102-6. CrossRef

18. Chiou SY, Lev-Toaff AS, Masuda E, Feld RI, Bergin D. Adnexal torsion: new clinical and imaging observations by sonography, computed tomography, and magnetic resonance imaging. J Ultrasound Med 2007;26:1289301.

19. Bider D, Mashiach S, Dulitzky M, Kokia E, Lipitz S, Ben-Rafael Z. Clinical, surgical and pathologic findings of adnexal torsion in pregnant and nonpregnant women. Surg Gynecol Obstet 1991;173:363-6.

20. Chapron C, Capella-Allouc S, Dubuisson JB. Treatment of adnexal torsion using operative laparoscopy. Hum Reprod 1996;11:998-1003. CrossRef

21. Chang HC, Bhatt S, Dogra VS. Pearls and pitfalls in diagnosis of ovarian torsion. Radiographics 2008;28:1355-68. CrossRef

22. Gaied F, Emil S, Lo A, Baird R, Laberge JM. Laparoscopic treatment of isolated salpingeal torsion in children: case series and a 20-year review of the literature. J Laparoendosc Adv Surg Tech A 2012;22:941-7. CrossRef

23. Oltmann SC, Fischer A, Barber R, Huang R, Hicks B, Garcia N. Cannot exclude torsion--a 15-year review. J Pediatr Surg 2009;44:1212-7. CrossRef

24. Meynol F, Steyaert H, Valla JS. Adnexal torsion in children: plea for early laparoscopic diagnosis and treatment. [Article in French] Arch Pediatr 1997;4:416-9. CrossRef

\section{OLGU SUNUMU - ÖZET}

\section{Çocuklarda izole tubal torsiyon: Olgu sunumu ve literatür değerlendirilmesi}

\section{Dr. Volkan Sarper Erikci, Dr. Münevver Hoşgör}

Dr. Behçet Uz Çocuk Hastalıkları ve Cerrahisi Eğitim ve Araştırma Hastanesi, Çocuk Cerrahisi Kliniği, Izmir

İzole tubal torsiyonlu (iTT) pediatrik ve adölesan popülasyondaki hikaye, klinik yansıma, fiziksel inceleme, laboratuvar bulgularının değerlendirilmesi ve belirlenmesi ile bu olguların cerrahi yönetiminin gözden geçirilmesi için çalışma gerçekleştirildi. Hastanemizde Ocak 2000 ile Aralık 2012 tarihleri arasında ITT tanısı ile tedavi edilen tüm olgular geriye dönük olarak incelendi. ITTT tanısı fiziksel inceleme, ultrasonografi (USG), renkli Doppler USG ve bilgisayarlı tomografiyi (BT) de içeren radyolojik çalışmalara dayanılarak konuldu ve cerrahi girişim ile doğrulandı. Çalışma döneminde iTT'li üç olgu bulunmaktadır. Olguların ikisi adölesan biri ise yenidoğan dönemindeydi. İki olguda sol tarafı iTT vardı. Yenidoğan olguda prenatal abdominopelvik kitle tanısı vardı. ITT'li diğer iki olgu semptomların başlamasından üç gün sonra başvurdu. Bu çalışmadaki tüm olgular salpenjektomi ile tedavi edildi. İzole tubal torsiyon ameliyat öncesi olarak nadiren tanınır ve en sıklıkla salpenjektomi ile tedavi edilir. Bu nadir durumun daha iyi tanınması tedavide ilerlemelere yardımcı olabilir. Adneksiyal torsiyonlardaki over koruyucu yaklaşım gibi, daha erken tanı ve mümkünse tubanın korunmasını da içeren çabuk cerrah girişim ile bu olguların ileriki dönem üreme potansiyelleri artırabilir.

Anahtar sözcükler: Çocuklar; izole tubal torsiyon; salpenjektomi.

Ulus Travma Acil Cerr Derg 2014;20(I):75-78 doi: 10.5505/tjtes.2014.26918 